УДК 347.441.8:347.447.63(477)

DOI https://doi.org/10.32837/yuv.v0i2.1710

\author{
В. Гончаренко, \\ кандидат юридичних наук, доцент, \\ доцент кафедри цивільного права \\ Національного університету «Одеська юридична академія» \\ https: / / orcid.org/0000-0001-9114-0276
}

\title{
ЗМІНА АБО РОЗІРВАННЯ ДОГОВОРУ У ЗВ'ЯЗКУ З ІСТОТНОЮ ЗМІНОЮ ОБСТАВИН
}

Стабільність договірних правовідносин та неухильне застосування принципу pacta sunt servanda $€$ необхідними умовами розвитку сталого суспільства. Істотна зміна обставин, якими сторони керувалися під час укладенні договору, набуває особливого ризикового значення під час виконання договору, що може привести до дисбалансу зобов'язань сторін договору.

У разі істотної зміни обставин за цивільним законодавством України належне виконання договору $€$ можливим, але істотно ускладненим. Зміна обставин $€$ істотною, якщо вони змінилися настільки, що, якби сторони могли це передбачити, вони не уклали б договір або уклали б його на інших умовах. Істотна зміна обставин може бути кваліфікована як вид непереборних (непередбачуваних) обставин. Проблема співвідношення таких видів непереборних обставин, як непереборна сила та випадок, та обставин, що істотно змінилися, сьогодні не знайшла свого відображення у цивілістичній літературі. У судовій практиці також відсутній єдиний підхід до вирішення спорів щодо зміни умов договору чи його розірвання 3 огляду на істотну зміну обставин, що робить виконання договору надмірно обтяжливим.

$\mathrm{Ha}$ практиці застереження про істотну зміну обставин сторони зазвичай взагалі не включають до змісту договору. Тому слід на теоретичному рівні провести аналіз істотної зміни обставин як підстави зміни або розірвання договору.
Динаміка цивільно-правового договору виступала предметом досліджень таких класичних цивілістів, як А. Венедиктов [1, с. 450], Е. Павлодський [2], M. Пергамент [3], В.А. Туманов [4], Л. Эннекцерус [5], а також сучасних дослідників (О. Ашурков [6], С. Бакунін [7], А. Буркова [8], Н. Вілкова [9], Н. Гаук [10], I. Канзафарова [11], Ю. Клюєва [12], А. Мискін [13], О. Осіпова [14], В. Примак [15], М. Сироєжкіна [16], С. Теньков [17], О. Хлонь [18] та ін.). Однак зазначені дослідження значною мірою присвячені непереборній силі як обставині, що звільняє від цивільно-правової відповідальності. При цьому недостатньо детально аналізується безпосередньо істотна зміна обставин, що не дає можливості розкрити сутність останньої цивільно-правової категорії.

Наявність різних видів обставин, що впливають на долю договору, необхідність ї правової кваліфікації визначають мету цього дослідження.

Об'єктом дослідження є правовідносини, пов'язані зі зміною або розірванням договору у зв'язку з істотною зміною обставин у цивільному праві України.

Предметом дослідження $€$ система правових норм, що регулюють відносини, пов'язані зі зміною або розірванням договору у зв'язку з істотною зміною обставин.

Відповідно до ст. 652 Цивільного кодексу України [19] (далі - ЦК Украіни) істотна зміна обставин, 3 яких сторони виходили під час укладення 
договору, є підставою для його зміни або розірвання, якщо інше не передбачено договором або не випливає із суті зобов'язання. При цьому зміна обставин визнається істотною, коли вони змінилися настільки, що, якби сторони могли це розумно передбачити, договір взагалі не був би ними укладений або був би укладений на умовах, що значно відрізняються.

Поняття «істотна зміна обставин» доволі складно визначити. Так, у Постанові Верховного Суду Украіни від 20.02.2012 р. зазначається, які обставини не можуть вважатися істотними для зміни чи розірвання договору за рішенням суду. Так, «настання світової фінансової кризи не $є$ істотною зміною обставин, якими сторони договору керувалися при його укладенні, оскільки економічна криза має загальний характер і стосується обох договірних сторін, отже, не може бути підставою для зміни або розірвання договору в судовому порядку» [20].

Істотна зміна обставин за своїм змістом є виявленням сторонами нової інформації, яка під час укладення договору не була їм відомою або ж сторони були впевнені у пї відсутності. Інформація про істотну зміну обставин вважається не відомою сторонам, якщо ними були вжиті всі заходи для їі отримання [21].

Так, у Постанові ВГСУ від 11.04.2017 року у справі № 910/32205/15 зазначається, що сама істотна зміна обставин не $€$ підставою для розірвання договору. Вимагаючи розірвання договору на цій підставі, позивач повинен довести, зокрема, впевненість сторін у момент укладення договору в тому, що така зміна обставин не настане [22].

Якщо сторони не досягли згоди щодо приведення договору у відповідність з обставинами, які істотно змінились, або щодо його розірвання, договір може бути розірваний, а з підстав, встановлених ч. 4 ст. 652 ЦК України, - змінений за рішенням суду на вимогу зацікавленої сторони за наявності одночасно таких умов: у момент укладення договору сторони виходили з того, що така зміна обставин не настане; зміна обставин зумовлена причинами, які зацікавлена сторона не могла усунути після їх виникнення при всій турботливості та обачності, які від неї вимагалися; виконання договору порушило б співвідношення майнових інтересів сторін і позбавило б заінтересовану сторону того, на що вона розраховувала при укладенні договору; із суті договору або звичаїв ділового обороту не випливає, що ризик зміни обставин несе зацікавлена сторона. Зміна договору у зв'язку 3 істотною зміною обставин допускається за рішенням суду у виняткових випадках, коли розірвання договору суперечить суспільним інтересам або потягне для сторін шкоду, яка значно перевищує витрати, які сторони понесуть для виконання договору на умовах, змінених за рішенням суду.

За загальним правилом, сторони не мають права вимагати зміни або розірвання договору за ст. 652 ЦК України. Так, наприклад, у договорі поставки сторони можуть чітко визначити, що ціни протягом дії договору не підлягають перегляду незалежно від дії будь-яких обстави (інфляції, коливання курсу валют тощо). У такому випадку сторони в договірному режимі визначають ризики за договором та позбавляють себе права звертатися до суду з односторонньою вимогою про зміну чи розірвання договору на підставі ст. 652 ЦК України. Зміна ціни договору в такому разі передбачається лише шляхом внесення змін до договору поставки за домовленістю сторін, однак не за рішенням суду.

У виняткових випадках, у зв'язку 3 незамінністю товарів, робіт, послуг, які надаються третіми особами, залученими для виконання основного зобов'язання, відмова останніх від продовження договірних відносин з основним боржником з не залежних від нього причин може вважатися істотною зміною обставин, достатньою для розірвання основного договору, якщо під час його 
укладення сторони виходили 3 того, що виконання буде фактично здійснюватися зазначеними третіми особами. 3 іншого боку, припинення або зміна основного договору може бути визнано істотною зміною обставин, достатньою для розірвання або зміни договорів із третіми особами, укладених на виконання зобов'язань за основним договором, якщо третім особам було відомо, для якої мети 3 ними вступають у договірні відносини. Наприклад, під час розірвання договору підряду із причин, за які генеральний підрядник не відповідає, останній може вимагати розірвання субпідрядних договорів із посиланням на ст. 652 ЦК України. Слід урахувати, що чинне цивільне законодавство про підряд цю ситуацію спеціально не регламентує.

Ризик погіршення економічної цінності предмета застави, що сталося від діi факторів ринку, змушений нести заставодержатель, а тому сторони договору про заставу повинні самі розробляти механізми, що дозволяють гарантувати відновлення економічної цінності предмета застави i, як наслідок, максимальне задоволення заставодержателя в разі його продажу.

Договір поруки, що забезпечує виконання виражених в іноземній валюті фінансових зобов'язань позичальника за кредитним договором, не припиняється i не може бути розірваний на вимогу поручителя у зв'язку 3 істотною зміною обставин, що виразилися в несприятливій для боржника і його поручителя зміні курсового співвідношення валют, наприклад, у результаті фінансової кризи.

Відкликання ліцензіі банку означає припинення його зобов'язань із банківської гарантії, так само як і обов'язків принципала щодо подальшої оплати послуг банку, навіть якщо в угоді банку-гаранта із принципалом про видачу гарантії міститься положення про інше [23, c. 11-12].

За рішенням суду розірвання договору відбувається в разі недосягнення згоди щодо приведення договору у від- повідність з обставинами, які істотно змінились, або щодо його розірвання. У разі розірвання договору внаслідок істотної зміни обставин суд, на вимогу будь-якої із сторін, визначає наслідки розірвання договору виходячи 3 необхідності справедливого розподілу між сторонами витрат, понесених ними у зв'язку з виконанням цього договору.

Слід відмітити, що положення ч. 2 ст. 652 ЦК України не покладають на зацікавлену сторону необхідність здійснення дій щодо усунення обставин, які істотно змінилися. Так само в таких джерелах цивільного права, як Принципи міжнародних комерційних договорів УНІДРУА [24] 2010 р., Принципи, визначення та модельні правила європейського приватного права - Проект «загальних критеріїв» (DCFR [25]), передбачається лише вимога відсутності причинно-наслідкового зв'язку між зміною обставин і діями зацікавленої сторони.

У випадку зміни договору зобов'язання сторін продовжують діяти відповідно до змінених умов щодо предмета, місця, строків виконання тощо. У разі розірвання договору зобов'язання сторін припиняються.

За загальним правилом, закріпленим у частині 4 ст. 653 ЦК України, сторони не мають права вимагати повернення того, що було виконане ними за зобов'язанням до моменту зміни або розірвання договору, якщо інше не встановлено договором або законом. Цим правилом, зокрема, зміна чи розірвання договору відрізняється від наслідків недійсності договору (правочину). Відповідно до ст. 236 ЦК України нікчемний правочин або правочин, визнаний судом недійсним, є недійсним із моменту його вчинення. Якщо за недійсним правочином права та обов'язки передбачалися лише на майбутнє, можливість настання $\ddot{\mathrm{ix}} \mathrm{y}$ майбутньому припиняється. За недійсним правочином зазвичай сторони повертаються в попередній стан, тобто кожна зі сторін повинна повернути другій у натурі все, що вона одержала на виконання цього право- 
чину, а при неможливості такого повернення - відшкодувати вартість у грошах. Законом можуть бути встановлені особливі правові наслідки окремих видів недійсних правочинів (ст. 216 ЦК України).

Особливі наслідки зміни чи розірвання договору можуть передбачатись окремими нормами закону. Так, відповідно до частини 3 ст. 652 ЦК у разі розірвання договору внаслідок істотної зміни обставин суд, на вимогу будь-якої із сторін, визначає наслідки розірвання договору, виходячи з необхідності справедливого розподілу між сторонами витрат, понесених ними у зв'язку з виконанням цього договору.

Відповідно до ч. 3 ст. 653 ЦК України в разі зміни або розірвання договору зобов'язання змінюється або припиняється 3 моменту досягнення домовленості про зміну або розірвання договору, якщо інше не встановлено договором чи не зумовлено характером його зміни. Якщо договір змінюється або розривається в судовому порядку, зобов'язання змінюється або припиняється 3 моменту набрання рішенням суду про зміну або розірвання договору законної сили. Таким чином, договір може бути розірваний або змінений, оскільки сторони не могли розумно передбачити відповідні ризики під час його укладення або оскільки прийнятий боржником на себе ризик виявився надзвичайно обтяжливим i в будьякому випадку істотно порушує майнові інтереси однієі зі сторін. Отже, за наявності істотної зміни обставин сторони договору не звільняються від цивільно-правової відповідальності. При цьому слід зазначити, що непереборна сила $є$ підставою звільнення від цивільно-правової відповідальності в тому разі, коли об'єктивна зовнішня обставина проявила себе зовні і наслідки іï прояву були надзвичайні та невідворотні для зобов'язаної особи.

За функціональним призначенням інститут обставин непереборної сили слугує встановленню підстав звільнення від цивільно-правової відпові- дальності, в той час як інститут істотної зміни обставин призначений підтримувати баланс інтересів сторін договору i забезпечувати неухильне виконання умов договору [26]. Якщо сторона посилається на обставину непереборної сили, то зазначене свідчить про абсолютну неможливість виконання зобов'язання незалежно від суб'єктивних чинників, тоді як істотна зміна обставин передбачає обов'язкове врахування індивідуальних характеристик сторони договору з передбачення і розподілу ризиків істотної зміни обставин.

Прикладом із судової практики стосовно підстав звільнення від відповідальності та підстав зміни або розірвання договору $є$ справа № 5016/561/2011(1/40), у якій позивач просить розірвати договір у зв'язку з істотною зміною обставин. В обгрунтування позовних вимог позивач посилається на негативну динаміку економічних змін у країні та на зростання ринкових цін на продукцію, що є предметом договору, та зазначає, що вказані обставини підпадають під поняття непереборної сили. Суд визнав посилання позивача на неможливість виконання своїх зобов'язань унаслідок непереборної сили безпідставними та погодився 3 доводами відповідача, що названі позивачем обставини за своєю суттю відносяться до ризиків підприємницької діяльності, а не є непереборною силою. Суд визнав позовні вимоги необгрунтованими та такими, що не підлягають задоволенню [27].

За загальним правилом зміна або розірвання договору вчиняються в такій самій формі, що й договір, який змінюється або розривається. Із цієї причини зміна чи розірвання нотаріально посвідченого договору також мають бути нотаріально посвідчені. Однак із положень самого договору, закону або зі звичаїв ділового обороту може випливати можливість зміни або розірвання договору в іншій формі, ніж сам договір. Так, за певних умов зміни в договір можуть вноситись конклюдентними діями однієї зі сторін у процесі вико- 
нання нею договору. Наприклад, відповідно до частин 1 і 2 ст. 1017 ЦК України комісіонер має право відступити від вказівок комітента, якщо цього вимагають інтереси комітента і комісіонер не міг попередньо запитати комітента або не одержав у розумний строк відповіді на свій запит. У цьому разі комісіонер має право повідомити комітента про допущені відступи від його вказівок, як тільки це стане можливим. Комісіонерові, який є підприємцем, може бути надано право відступати від вказівок комітента без попереднього запиту про це, але з обов'язковим повідомленням комітента про допущені відступи.

Порядок зміни і розірвання господарських договорів передбачено ст. 188 ГK України [28]. Сторона договору, яка вважає за необхідне змінити або розірвати договір, надсилає пропозицію другій стороні. Остання у двадцятиденний строк після одержання пропозиції повідомляє контрагента про результати ii розгляду. У разі якщо сторони не досягли згоди щодо зміни (розірвання) договору або в разі неодержання відповіді у встановлений строк з урахуванням часу поштового обігу зацікавлена сторона має право передати спір на вирішення суду.

Якщо судовим рішенням договір змінено або розірвано, договір вважається зміненим або розірваним із дня набрання чинності даним рішенням, якщо іншого строку набрання чинності не встановлено за рішенням суду (частина 5 ст. 188 ГК).

Таким чином, позиція законодавця щодо зміни або розірвання договору в разі істотної зміни обставин заснована на тому, що участь у господарському обороті передбачає прийняття сторонами договору на себе ризику зміни обставин, а тому, за загальним правилом, сторони не мають права вимагати зміни або розірвання договору за ст. 652 ЦК України. Законодавець надає перевагу розірванню договору в разі істотної зміни обставин, ніж можливості внесення змін до наявного договору за рішенням суду.
Основними наслідками істотної зміни обставин, якими сторони керувалися під час укладення договору, є: 1) зміна умов договору за умови збереження самого договору в силі за згодою сторін або за рішенням суду у виняткових випадках, коли розірвання договору суперечить суспільним інтересам або потягне для сторін шкоду, яка значно перевищує затрати, необхідні для виконання договору на умовах, змінених судом, або 2) розірвання договору за згодою сторін або за рішенням суду.

Зобов'язання змінюється або припиняється в разі зміни або розірвання договору з моменту досягнення домовленості про зміну або розірвання договору, якщо інше не встановлено договором чи не зумовлено характером його зміни. У судовому порядку зміни або розривання договору зобов'язання змінюється або припиняється 3 моменту набрання рішенням суду про зміну або розірвання договору законної сили. Хоча сторони не мають права вимагати повернення того, що було виконане ними за зобов'язанням до моменту зміни або розірвання договору, суд, на вимогу будь-якої зі сторін, може визначити наслідки розірвання договору виходячи з необхідності справедливого розподілу між сторонами витрат, понесених ними у зв'язку з виконанням цього договору.

У статті охарактеризовані теоретичні та практичні питання зміни або розірвання договору у зв'язку з істотною зміною обставин.

Визначено, щз в разі істотної зміни обставин за ицвільним законодавством України належне виконання договору є можливим, але icmomно ускладненим. Зміна обставин є істотною, якщо вони змінилися настільки, щзо, якби сторони могли ие передбачити, вони не уклали б договір або уклали б його на інших умовах. Істотна зміна обставин може бути кваліфікована як вид непереборних (непередбачуваних) обставин. Проблема співвідношення 
таких видів непереборних обставин, як непереборна сила та випадок, та обставин, що істотно змінилися, на сьогодні не знайщла свого відображення в изивілістичній літературі. У судовій практиці також відсутній єәиний підхід до вирішення спорів щодо зміни умов договору чи його розірвання з огляду на істотну зміну обставин, щз робить виконання договору надмірно обтяжливим. У роботі розглянуто питання про співвідношення понять «істотна зміна обставин» та «комериійний ризик». Договір може бути розірваний або змінений, оскільки сторони не могли розумно передбачити відповідні ризики під час його укладення, або оскільки прийнятий боржником на себе ризик виявився надзвичайно обтянливим $i$ в будь-якому випадку істотно порушуе майнові інтереси однієї зі сторін.

За загальним правилом, сторони не мають права вимагати зміни або розірвання договору за ст. 652 ЦК України. Законодавець надає перевагу розірванню договору в разі істотної зміни обставин, ніж можливості внесення змін до наявного договору за рішенням суду.

Основними наслідками істотної зміни обставин, якими сторони керувалися під час укладення договору, є: 1) зміна умов договору при збереженні самого договору в силі за згодою сторін або за рішенням суду у виняткових випадках, коли розірвання договору суперечить суспільним інтересам або потягне для сторін шкоду, яка значно перевищує затрати, необхідні для виконання договору на умовах, змінених судом, або 2) розірвання договору за згодою сторін або за рішенням суду.

На підставі проведеного дослідження запропоновані зміни до циивільного законодавства України.

Ключові слова: договір, застереження про незмінність умов договору, істотна зміна обставин, непереборна сила, ризик, форс-мажор.
Goncharenko V. Change or termination of the contract due to a significant change of circumstances

The article describes the theoretical and practical issues of changing or terminating the contract due to a significant change of circumstances.

It is determined that a significant change of circumstances under the civil legislation of Ukraine is a special category of unforeseen circumstances, in the occurrence of which proper implementation is possible, but due to their unpredictability is significantly complicated. Circumstances of force majeure (force majeure) can theoretically always be qualified as a significant change of circumstances. The main difference between a significant change of circumstances and force majeure is the consequences: the party referring to such a change of circumstances may require a change in the terms of the contract for fair performance, as well as termination of the contract (Article 652 of the Civil Code of Ukraine). If the party refers to the circumstances of force majeure, proper performance of the obligation by the debtor is impossible, and therefore the party is released from liability for breach of obligation. In this case, the parties to the contract are not deprived of the right to predict the consequences of force majeure in the form of termination or amendment of the contract.

As a general rule, the parties have no right to demand a change or termination of the contract under Art. 652 of the Civil Code of Ukraine. The legislator prefers the termination of the contract in the event of a significant change of circumstances than the possibility of amending the existing contract by court order.

The main consequences of a significant change in the circumstances that guided the parties in concluding the contract are: 1) change in the terms of the contract while maintaining the contract in force by agreement of the parties or by court decision in exceptional cases where termination 
of the contract significantly exceeds the costs necessary to perform the contract on terms changed by the court. or 2) termination of the contract by agreement of the parties or by court decision.

Based on the study, changes to the civil legislation of Ukraine are proposed.

Key words: contract, clausula rebus sic stantibus, significant change of circumstances, force majeure, risk, force majeure.

\section{Література}

1. Венедиктов А.В. Избранные труды по гражданскому праву. В 2-х томах. Т. $1 /$ Науч. ред.: А.А. Иванов. Москва : Статут, 2004. 463 c. C. $450,458$.

2. Павлодский E.A. Случай и непреодолимая сила в гражданском праве. Москва: Юрид. лит., 1978. 104 c.

3. Пергамент М.Я. Война и «непреодолимая сила». Петроград : тип. т-ва «Обществ. польза», 1914. 23 с.

4. Туманов В.A. "Случай» $и$ «непреодолимая сила» в советском гражданском праве : автореф. дис. ... канд. юрид. наук. Москва, 1951. 14 с.

5. Эннекцерус Л. Курс германского гражданского права. Т. 1 / Под ред. Д.М. Генкина, И.Б. Новицякого. Москва : Иностран. лит, 1950. 483 с.

6. Ацурков О.А. Особенности освобождения от ответственности за неисполнение договорных обязательств в Украине. Трансформація юридичної відповідальності на сучасному етапі розвитку суспільства. Донещьк, 2008. С. 13-16.

7. Бакунин С.Н. Непреодолимая сила как основание освобождения воздушного перевозчика от гражданско-правовой ответственности в случае причинения вреда. Цивилист. 2009. № 4. С. 44-47.

8. Буркова А. Форс-мажор. Юрист. 2008. № 10. C. 44-47.

9. Вилкова Н. Совпадает ли форс-мажорная оговорка контракта с понятием форс-мажора? Хозяйство и право. 2008. № 4. C. 48-55.

10. Гаук Н. Що таке форс-мажор? Юридичний блокнот. № 92(1125) 6 жовтня 2005 року. C. 23-25.

11. Канзафарова I.C., Драганов С.С. Кваліфікуючі ознаки обставин непереборної сили: доктринальні підходи.
URL : https://drive.google.com/file/d/OBJOt0RB3nb8ZDBiZ0lkQ05UeDQ / view.

12. Клюєва Ю.О. Обстоятельства, исключающие гражданско-правовую ответственность: отдельные вопросы их толкования. Римське право і сучасність (Шерещевські читання) / НУ «ОЮА». Ч. 1. 2012. C. 146-148.

13. Мыскин А.В. Категория «случай» в гражданском праве. Российская юстищия. 2012. № 10. C. 8-12.

14. Осіпова О.О.Форс-мажорніобставини в договорі банківського вкладу (депозиту). URL : http://lib.uabs.edu.ua/library/P_ Visnik / Numbers /2_5_2011/05_04_05.pdf.

15. Примак В. Ознаки непереборноі сили у відносинах иивільно-правової відповідальності. Юридична Україна. 2008. № 6. C. 60-67.

16. Сыроежкина М.С. Основания освобождения предпринимателей от гражданско-правовой ответственности. Юрист. 2010. № 6. C. 18-22.

17. Теньков С. Форс-мажор у судовій практиці. Комериійні ризики на тимчасово окупованих територіях. Юридичний вісник України. 2014. 17-24 листопада (№ 46).

18. Хлонь О. Форс-мажор та непереборна сила: їх розмежування у иивільному праві. Право України. 2005. № 1. С. 112-114.

19. Цивільний кодекс України : Закон України від 16.01.2003 р. № 435-IV. Офіційний вісник України. 2003. № 11. Ст. 461.

20. Постанова Верховного Суду України вid 20.02.2012 p. URL : http: / / www.scourt. gov.ua/.

21. Назыков А.Л. «Оговорка о неизменности обстоятельств» и ее рецепция в российском гражданском праве (CLAUSULA REBUS SIC STANTIBUS) : aвmopeф. duc. ... канд. юрид. наук : 12.00 .03 Ростов-наДону, 2007.

22. Постанові ВГСУ від 11.04 .2017 року у справi № 910/32205/15. URL : https: / / protocol.ua/ua/postanova_vgsu_ vid_11_04_2017_roku_u_spravi_910_ 32205_15/.

23. Назыков А.Л. «Оговорка о неизменности обстоятельств» и ее рецепиия в российском гражданском праве (CLAUSULA REBUS SIC STANTIBUS) : автореф. дис. ... канд. юрид. наук : 12.00.03. Ростов-наДону, 2007.

24. Принщипи міжнародних комериійних договорів УНІДРУА (UNIDROIT) 2010. URL : http: / / www.unidroit.org / english/ principles / contracts / principles2010 / translations / blackletter2010-ukranian.pdf. 
25. Principles, Definitions and Model Rules of European Private Law. Draft Common Frame of reference (DCFR). Full Edition. Prepared by the Study Group on a European Civil Code and the Research Groupon EC Private Law (Acquis Group) / Ed. by Christian von Barand Eric Clive. Vol. I VI. Munich, 2009. 4795 p. URL : http://ec.europa.eu/ justice / contract / files / european-privatelaw_en.pdf.
26. Очхаев Т.Г. Изменение и расторжение договора в связи с существенным изменением обстоятельств : дисс. ... канд. юрид. наук : 12.00.03. Москва, 2015.

27. Рішення Господарського суду Миколаївської області від 5 квітня 2011 p. № 5016/561/2011(1/40). URL : http:/ / www.reyestr.court.gov.ua/Review/14882814.

28. Господарський кодекс України. Офіційний вісник України. 2003 р. № 1. С. 303. Ст. 462. 